ISSN Print : $1411-951 \mathrm{X}$, ISSN Online : 20503-1716

Jurnal Ergonomi Indonesia

(The Indonesian Journal of Ergonomic)

Vol.3, No.2 : 1 Juli-Desember 2017

\title{
PENGGUNAAN PAKAIAN DINAS HARIAN BERLENGAN PENDEK DAPAT MENINGKATKAN KENYAMANAN DAN KINERJA RADIOGRAFER DI RUMAH SAKIT UMUM PUSAT SANGLAH DENPASAR
}

\author{
${ }^{1}$ I Made Purwa Damita, ${ }^{2}$ I Putu Gede Adiatmika, ${ }^{3}$ Luh Made Indah Sri Handari Adiputra, \\ 1. Mahasiswa Program studi Magister Ergonomi-Fisiologi Kerja, Universitas Udayana. \\ 2. Staff dosen Program studi Magister Ergonomi-Fisiologi Kerja, Universitas Udayana. \\ 3. Staff Dosen Program studi Magister Ergonomi-Fisiologi Kerja, Universitas Udayana. \\ purwadarmita@yahoo.com
}

\begin{abstract}
Technological developments increase the clothing industry from a variety of materials, types of fabrics, clothing models used by various professions in the form of work uniforms or daily service clothing (PDH). The convenient use of PDH helps workers improve their performance. This study was conducted to determine the effect of long-sleeved and short-sleeved PDH on the comfort and performance of radiographers at Sanglah Hospital Denpasar. This research was carried out at radiology installation of Sanglah Denpasar Hospital, from May to June 2017. The design of this study was cross-design of two equal period subjects (treatment by subject and two period cross over pre and post-test group design) with a total sample of 16 people. The use of long-sleeved PDH as a control group, short-sleeved PDH as the treatment group. Measurements were performed pre and post on the comfort and performance of radiographers in terms of hand washing time and the number of patients that could be served. Comparison test on comfort and performance using Wilxocon Signed Ranks Test with $\mathrm{p}<0,05$. The results showed that the application short-sleeved PDH increased the subjective comfort y 10.75 or $27.08 \%$ ( $\mathrm{p}<0.05$ ), improving the performance of decreasing the time duration score required by hand washing 0,87 or $34,12 \% \mathrm{p}<0.05$ ) and an increase in the number of patients who could be served by 6.31 or $53.98 \%$ ( $p<0.05$ ).

The applicastion of short-sleeved PDH compared to long-sleeved PDH showed a difference of comfort and radiographer performance at radiology installation of Sanglah Hospital Denpasar. The next PDH manufacturing process for radiographers is recommended using short-sleeved PDH.
\end{abstract}

Keywords: Long-sleeved and short-sleeved PDH, comfort, performance, radiology

\section{INTISARI}

Perkembangan teknologi meningkatkan industri sandang dari berbagai bahan, jenis kain, model pakaian yang digunakan oleh berbagai profesi dalam bentuk seragam kerja atau pakaian dinas harian (PDH). Penggunaan PDH yang nyaman, membantu pekerja meningkatkan kinerjanya. Penelitian ini dilakukan untuk mengetahui pengaruh PDH berlengan panjang dan berlengan pendek terhadap kenyamanan dan kinerja radiografer di RSUP Sanglah Denpasar. Penelitian ini dilaksanakan di instalasi radiologi RSUP Sanglah Denpasar, pada bulan Mei sampai Juni 2017. Desain penelitian ini rancangan silang dua periode sama subjek (treatment by subject and two period cross over pre and post-test group design) dengan jumlah sampel 16 orang. Penggunaan PDH berlengan panjang sebagai kelompok kontrol, PDH berlengan pendek sebagai kelompok perlakuan. Pengukuran dilakukan pre dan post terhadap kenyamanan dan kinerja radiografer yang ditinjau dari durasi 


\section{Jurnal Ergonomi Indonesia}

waktu mencuci tangan serta jumlah pasien yang bisa dilayani. Uji komparasi terhadap kenyamanan dan kinerja menggunakan uji Wilxocon Signed Ranks Test dengan $\mathrm{p}<0,05$. Hasil penelitian menunjukkan penggunaan PDH berlengan pendek dapat meningkatkan skor kenyamanan subjektif sebesar 10,75 atau 27,08\% ( $<<0,05)$, meningkatkan kinerja yaitu penurunan durasi waktu yang dibutuhkan mencuci tangan sebesar 0,87 atau 34,12\% ( $<0,05)$ dan peningkatan skor jumlah pasien yang bisa dilayani sebesar 6,31 atau 53,98\% ( $<<0,05)$. Penggunaan PDH berlengan pendek dibandingkan PDH berlengan panjang menunjukkan adanya perbedaan kenyamanan dan mempengaruhi kinerja radiografer di instalasi radiologi RSUP Sanglah Denpasar. Proses pembuatan PDH berikutnya untuk radiografer disarankan menggunakan PDH berlengan pendek.

Kata kunci : PDH berlengan panjang dan pendek, kenyamanan, kinerja, radiologi

\section{PENDAHULUAN}

Perkembangan

memudahkan manusia memenuhi kebutuhan dan gaya hidupnya. Perkembangan ini menyebabkan muncul berbagai model pakaian yang disesuaikan dengan aktivitas sehari - hari, pakaian kerja di kantor pun ikut berkembang dan diseragamkan, sehingga disebut pakaian seragam, Pakaian seragam mempunyai fungsi : (1) Menjadi identitas pekerja dan institusi juga menjadi media promosi selain untuk kepentingan profesionalisme dan memperlihatkan kemampuan institusi; (2) Upaya fungsional untuk optimalisasi melindungi tubuh dan memberikan rasa nyaman, aman serta sehat, sesuai dengan situasi dan kondisi lingkungan; (3) Merefleksikan jenis pekerjaan, departemen, jabatan dan waktu pemakaiannya (Valentino, 2016).

Pakaian seragam yang disebut juga pakaian dinas umumnya digunakan oleh Pegawai Negeri Sipil (PNS) untuk membedakannya dengan masyarakat umum ketika bertugas. PNS di seluruh Indonesia diharapkan memiliki disiplin tinggi, mampu memberikan pelayanan yang terbaik untuk masyarakat, dengan mengacu pada parameter kinerja. yang diatur pada P P No. 53/2010.. PNS yang memberikan pelayanan kesehatan di Rumah Sakit Umum Pusat (RSUP) Sanglah Denpasar juga menggunakan Pakaian Dinas Harian (PDH), sesuai dengan peraturan Kementerian Kesehatan
Republik Indonesia (Kemenkes RI No 12 tahun 2015).

Radiografer adalah PNS yang diberi tugas, tanggung jawab, wewenang dan hak secara penuh untuk melakukan kegiatan pelayanan radiologi pada sarana kesehatan (Permen PAN RB RI, 2013). Radiografer di RSUP Sanglah Denpasar dalam memberikan pelayanan radiologi, berhubungan langsung dengan pasien untuk memastikan diagnose suatu penyakit. Radiografer dalam memberikan pelayanan diagnostik diharapkan menerapkan program Safety Patient sebagai budaya kerja untuk mencegah dan menurunkan angka kejadian yang tidak diharapkan. Salah satu syarat penerapan safety patient adalah melakukan cuci tangan sebelum dan setelah kontak dengan pasien, setelah kontak dengan sekitar pasien, sebelum melakukan prosedur aseptik dan setelah menyentuh cairan tubuh/ekskresi pasien (Tim KP-RS, 2011).

Menurut Manuaba (2005), beban kerja petugas rumah sakit jauh lebih besar dibandingkan dengan beban petugas pelayanan di tempat lainya. Radiografer di RSUP Sanglah Denpasar, sikap kerjanya bervariasi antara duduk, berdiri dan duduk berdiri secara bergantian. Sikap kerja ini mempertimbangkan kemampuan, kebolehan dan keterbatasan manusia. Beban kerja ini akan terasa lebih, bila dalam melakukan aktivitas kerja fisik ditambah lagi beban kerja mental yang dapat menimbulkan kelelahan dan ketidaknyamanan, karena overload pekerjaan (Grandjean, 2015). 


\section{Jurnal Ergonomi Indonesia}

\section{(The Indonesian Journal of Ergonomic)}

PDH berlengan panjang menjadi keluhan radiografer dalam melaksanakan pelayanan radiologi. Keluhannya seperti: (1) Pakaian terasa agak berat, terasa sempit didaerah pergelangan tangan, rasa kaku di daerah siku, bahu dan punggung; (2) Badan terasa lebih cepat panas karena pori-pori kain yang rapat dan menutup sampai ke pergelangan tangan sehingga penguapan tubuh menjadi lebih lama; (3) Risiko terinfeksi nosokomial akibat terpapar darah atau cairan tubuh pasien yang menempel di lengan PDH dan bisa tercuci bersih setelah sampai di rumah; (4) Pemeriksaan pasien menjadi lebih lama karena diperlukan waktu tambahan untuk melipat lengan baju sewaktu melakukan cuci tangan sebelum dan setelah pemeriksaan radiologi. Keluhan radiografer ini dipengaruhi oleh kondisi fisik, sikap kerja, maupun kondisi lingkungannya.
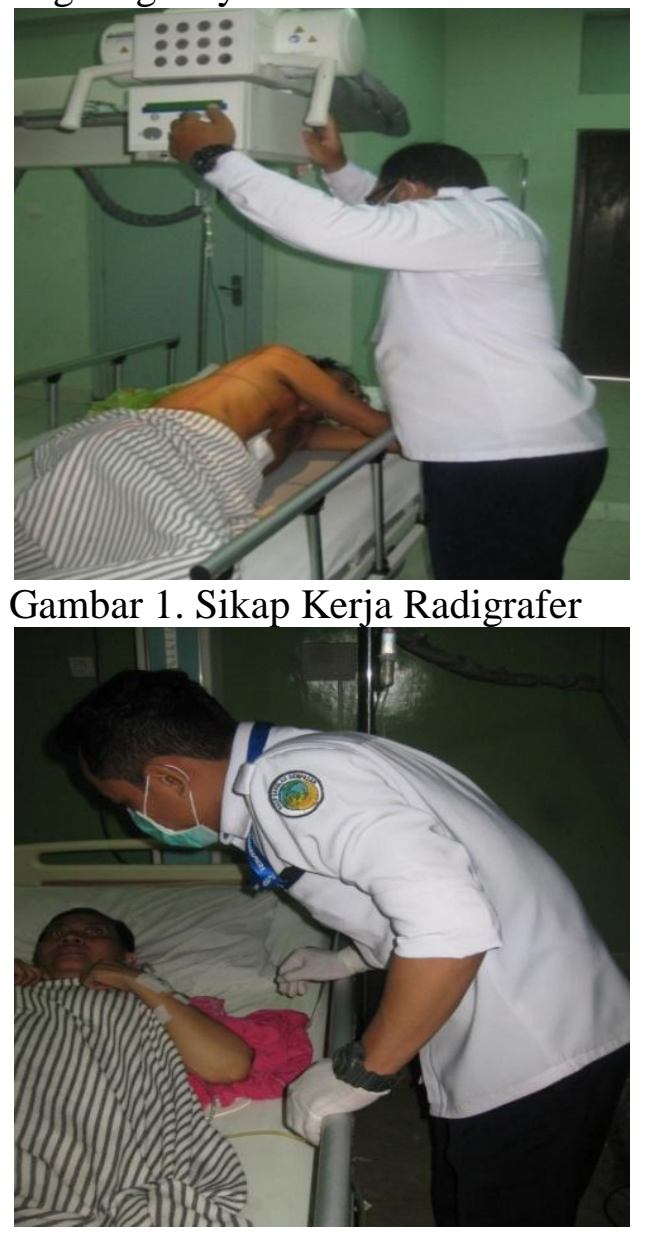

Gambar 2. Sikap Kerja radiografer

Upaya mengatasi keluhan yang dirasakan oleh radiografer di Instalasi
Vol.3, No.2 : 1 Juli-Desember 2017

$\begin{array}{llr}\text { Radiologi } & \text { RSUP } & \begin{array}{r}\text { Sanglah } \\ \text { berlengan }\end{array} \\ \text { terhadap } & \text { PDH } & \text { panjang, }\end{array}$ dilakukan melalui intervensi PDH menjadi berlengan pendek disesuaikan dengan PDH yang dipakai oleh tenaga medis keperawatan, karena radiografer sebagai tenaga medis penunjang non keperawatan juga bersentuhan langsung dengan pasien dan berisiko terinfeksi nosokomial.

\section{MATERI DAN METODE}

Kenyamanan adalah perasaan yang muncul akibat dari minimalnya atau tidak adanya gangguan pada sensasi tubuh (Manuaba,1998). Menurut Kolcaba, dalam Potter dan Penry (2005) kenyamanan atau rasa nyaman adalah suatu keadaan telah terpenuhinya kebutuhan dasar manusia seperti (1) Kebutuhan ketentraman yaitu suatu kepuasan yang meningkatkan penampilan sehari-hari, (2) Kelegaan yaitu telah terpenuhinya segala kebutuhan, dan (3) Transenden yaitu keadaan tentang sesuatu yang melebihi masalah dan nyeri.

Sensasi ketidaknyamanan timbul bila keadaan/ suasana diluar kenormalan, bisa meningkat mulai dari terasa mengganggu sampai menimbulkan rasa sakit tergantung dari seberapa jauh keseimbangan terganggu. Sensasi kenyamanan terjaga dengan meningkatkan metabolisme, merubah level aktivitas otot, atau menggunakan pakaian, bisa juga dengan memodifikasi lingkungan dengan bantuan alat/ teknologi. Ketidaknyamanan dapat menimbulkan perubahan fungsional yang bisa mempengaruhi seluruh tubuh. Panas berlebih (overheating) menyebabkan kelelahan meningkat, rasa kantuk, performance fisik menurun dan meningkatkan kemungkinan kesalahan (error). Perbaikan kondisi kenyamanan di dalam ruangan sangat penting untuk kesehatan dan performance secara maksimal (Kroemer dan Grandjean,2000).

Pakaian adalah faktor pilihan yang mudah diterapkan untuk mencapai kenyamanan suhu tubuh. Manusia bisa 


\section{Jurnal Ergonomi Indonesia}

\section{(The Indonesian Journal of Ergonomic)}

memilih dan menentukan jenis dan model pakaian yang dikenakan untuk mencapai kenyamanan suhu tubuhnya. Indeks penguapan pakaian $($ clothing value $=$ clo) tiap jenis pakaian bisa digunakan untuk menghitung tingkat kenyamanan pakaian yang hendak digunakan (Ogulata R, 2007).

$$
\text { Menurut Manuaba }
$$

keserasian alat, cara dan lingkungan kerja terhadap kemampuan, kebolehan dan batasan manusia untuk memperoleh kondisi kerja dan lingkungan yang sehat, aman, nyaman, juga efisien sehingga tercapai hasil kerja yang setinggi tingginya. Oleh karena itu pengendalian dan penanganan faktor-faktor internal yang bersifat somatis dan psikis serta faktor eksternal yang berupa task, organisasi dan lingkungan kerja fisik maupun psikis harus ditangani secara berkesinambungan.

Pelayanan kesehatan menurut Departemen Kesehatan RI, 2010 adalah penampilan/kinerja yang menunjuk pada tingkat kesempurnaan pelayanan kesehatan, yang dapat menimbulkan kepuasan pada setiap pasien sesuai dengan tingkat kepuasan rata-rata penduduk, serta tata cara penyelenggaraannya sesuai dengan standar dan kode etik profesi yang telah ditetapkan. Penilaian kinerja merupakan salah satu tahapan penting dalam siklus pengembangan SDM yang dilakukan secara objektif, terukur, akuntabel, partisipasif dan transparan. Menurut UU No 5, 2014 penilaian kinerja PNS bertujuan untuk menjamin objektivitas pembinaan PNS yang didasarkan pada sistem prestasi dan sistem karier dengan memperhatikan target, capaian, hasil dan manfaat yang dicapai, serta perilaku PNS. Mangkunegara (2005) menyebutkan bahwa kinerja adalah prestasi kerja atau hasil kerja (output) berupa kualitas maupun kuantitas yang dicapai sumber daya manusia per satuan periode waktu, sesuai dengan tanggung jawab yang diberikan kepadanya. Rivai (2005) menjelaskan bahwa hakikat kinerja merupakan prestasi yang dicapai oleh seseorang dalam melaksanakan tugas atau pekerjaan sesuai dengan standar dan kriteria yang ditetapkan untuk pekerjaan itu.

Konsep penelitian ini yaitu :

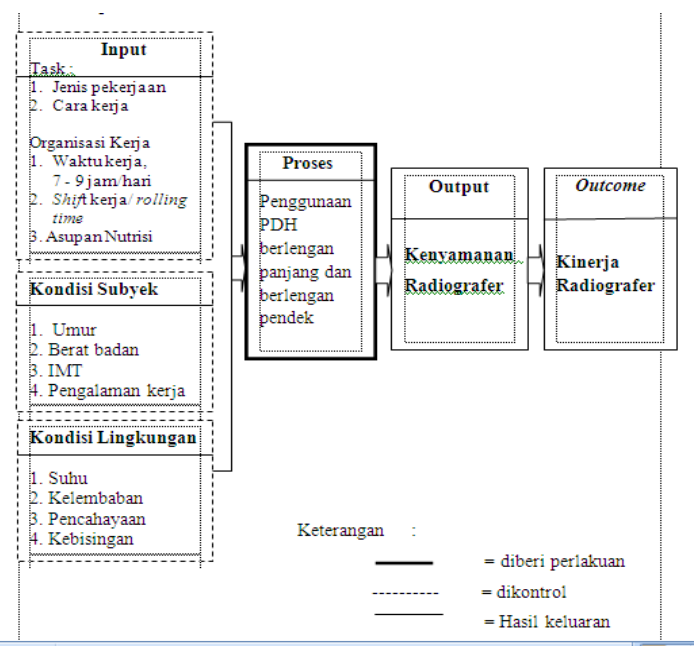

Penelitian ini adalah eksperimental sungguhan, dengan rancangan silang dua periode sama subjek (Treatment by subject Two Period Cross Over Design), (Bakta 2000; Pocock, 2008)

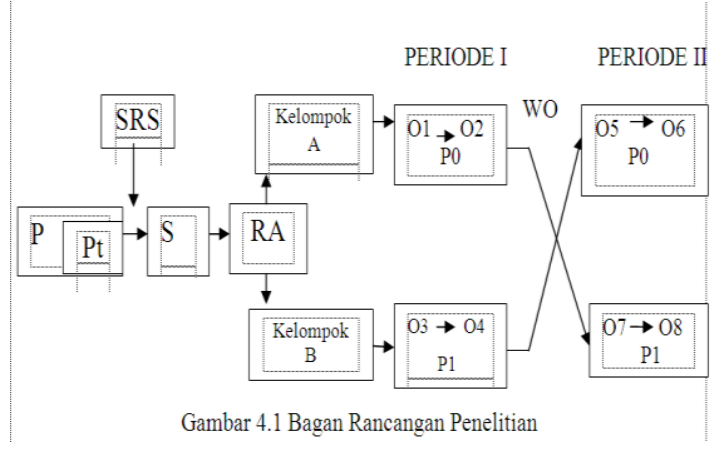

\section{HASIL DAN PEMBAHASAN}

1. Kenyamanan

Analisis selanjutnya untuk mengetahui perbedaan kenyamanan dlakukan uji Wilcoxon Signed Ranks test. Hasil datanya menunjukkan nilai kenyamanan sebelum bekerja tidak berbeda bermakna $(p>0,05)$ dengan nilai $\mathrm{z}=-1,83$ dan nilai $\mathrm{p}=0,07$ Artinya kenyamanan subjek sebelum melakukan pelayanan untuk kedua kelompok adalah komparabel, sehingga dapat diasumsikan bahwa peningkatan skor kenyamanan pada kelompok perlakuan disebabkan oleh adanya 
ISSN Print : 1411 -951 X, ISSN Online : 20503-1716

\section{Jurnal Ergonomi Indonesia}

\section{(The Indonesian Journal of Ergonomic)}

penggunaan PDH berlengan pendek. Analisis untuk skor kenyamanan setelah melakukan pelayanan digunakan Wilcoxon Signed Ranks test didapatkan hasil berbeda bermakna $(\mathrm{p}<0,05)$ dengan nilai $\mathrm{z}=-3,53$ dan $\mathrm{p}=0,01$. Hal ini berarti bahwa intervensi PDH berlengan pendek dapat meningkatkan kenyamanan subjek setelah melakukan pelayanan radiologi. Peningkatan skor kenyamanan pada kelompok perlakuan memiliki rerata sebesar $10,75(27,08 \%)$.

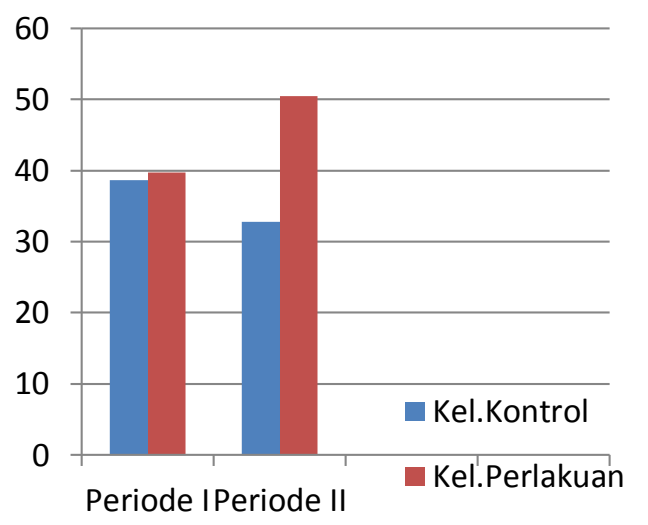

Kenyamanan subjek sebelum melakukan pelayanan untuk kedua kelompok adalah komparabel, sehingga dapat diasumsikan bahwa peningkatan skor kenyamanan pada kelompok perlakuan disebabkan oleh adanya penggunaan PDH berlengan pendek. Analisis untuk skor kenyamanan setelah melakukan pelayanan digunakan Wilcoxon Signed Ranks test didapatkan hasil berbeda bermakna $(\mathrm{p}<0,05)$ dengan nilai $\mathrm{z}=-3,53$ dan $\mathrm{p}=0,01$. Hal ini berarti bahwa intervensi PDH berlengan pendek dapat meningkatkan kenyamanan subjek setelah melakukan pelayanan radiologi. Peningkatan skor kenyamanan pada kelompok perlakuan memiliki rerata sebesar $10,75(27,08 \%)$.

\section{Kinerja}

a. Durasi Waktu mencuci tangan

Hasil uji Independent Samples terhadap durasi waktu mencuci tangan dapat dilihat pada grafik berikut

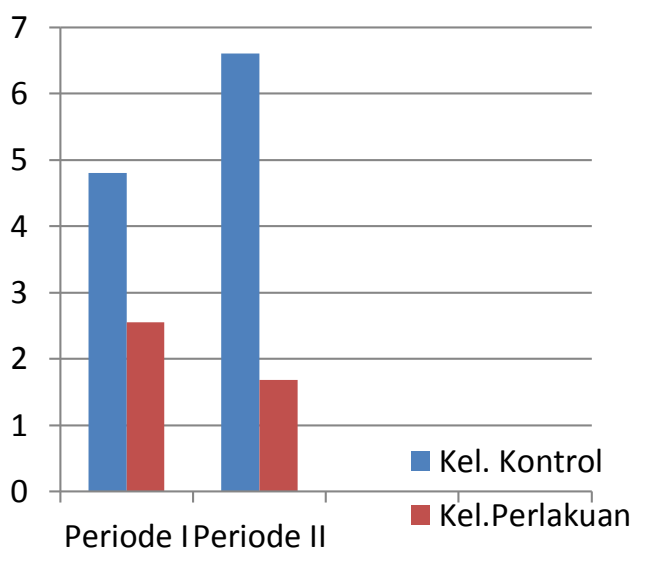

Durasi waktu mencuci tangan setelah bekerja berbeda bermakna $(\mathrm{p}<0,05)$ dengan nilai $\mathrm{z}=-3,53$ dan nilai $\mathrm{p}=0,01$. Artinya durasi waktu mencuci tangan untuk kedua kelompok adalah komparabel atau sangat berbeda bermakna, sehingga dapat diasumsikan bahwa penurunan skor durasi waktu mencuci tangan disebabkan oleh adanya intervensi penggunaan $\mathrm{PDH}$ berlengan pendek. Penurunan skor waktu untuk mencuci tangan pada kelompok perlakuan sebesar $0,87(34,12 \%)$

3. Jumlah Pasien yang bisa dilayani

Hasil analisis menunjukkan peningkatan jumlah pasien yang bisa dilayani disebabkan intervensi PDH berlengan pendek. . Hasil uji Shapiro Wilk menunjukan data berdistribusi tidak normal $(\mathrm{p}<0,05)$. Analisis selanjutnya untuk mengetahui perbedaan jumlah pasien yang dilayani dlakukan uji Wilcoxon Signed Ranks test. Hasil dalam bentuk grafik sebagai berikut :

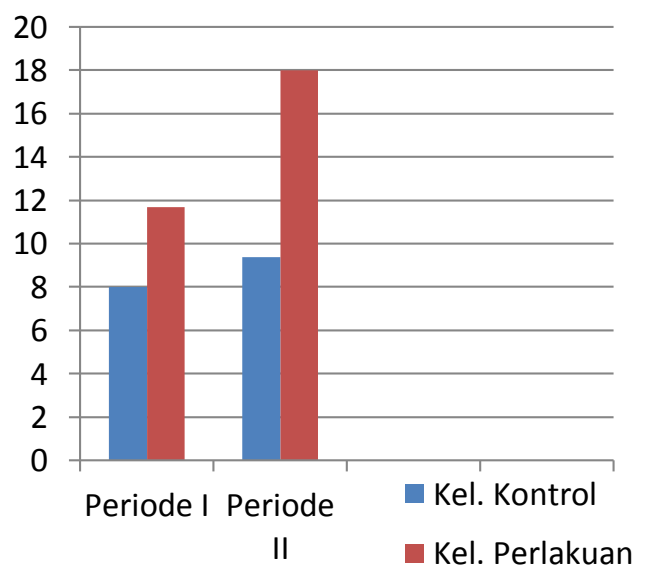

Grafik ini menunjukkan bahwa intervensi penggunaan PDH berlengan 


\section{Jurnal Ergonomi Indonesia}

\section{(The Indonesian Journal of Ergonomic)}

pendek dapat meningkatkan jumlah pasien yang bisa dilayani dengan rerata sebesar 6,31 ( 53,98\%). Secara grafik peningkatan jumlah pasien yang bisa dilayani oleh kelompok perlakuan dibandingkan dengan kelompok kontrol dapat dilihat grafik diatas.

\section{Pembahasan}

\section{a. Kenyamanan}

Kenyamanan subjektif radiografer adalah meningkatnya rasa nyaman, tidak adanya tekanan baik fisik maupun psikis dalam melaksanakan aktivitas pelayanan di radiologi, sehingga akan berdampak terhadap meningkatnya kinerja radiografer. Hal ini sesuai dengan pendapat Manuaba (1998) yang menyatakan kenyamanan adalah perasaan yang muncul akibat dari minimalnya atau tidak adanya gangguan pada sensasi tubuh, sesuai juga dengan pendapat Kolcaba, dalam Potter dan Penry (2005) kenyamanan adalah suatu keadaan telah terpenuhinya kebutuhan akan ketentraman, kelegaan maupun masalah terhadap asa nyeri. Kenyamanan lingkungan kerja berdasarkan pendekatan suhu mempengaruhi psikologis dan bersifat subjektif (Hoppe dalam Sugini, 2004). Kenyamanan suhu ini berhubungan dengan aspek fisik, fisiologis dan psikologis (ASHARE, 1992).

\section{b. Kinerja}

1). Durasi Waktu mencuci tangan

Rerata durasi waktu mencuci tangan diawal melaksanakan pelayanan di instalasi radiologi pada Periode I untuk kelompok kontrol adalah 4,81+0,19 dan untuk kelompok perlakuan adalah $2,55 \pm 0,13$. Sementara rerata durasi waktu mencuci tangan diawal melaksanakan pelayanan di instalasi radiologi pada Periode II untuk kelompok kontrol adalah 6,61 $\pm 0,19$ dan kelompok perlakuan adalah $1,68 \pm 0,17$. Hasil uji beda skor durasi waktu mencuci tangan pada kedua kelompok setelah melakukan pelayanan radiologi menunjukkan berbeda bermakna $(\mathrm{p}<0,05)$. Artinya perbedaan skor durasi waktu mencuci tangan diawal Periode I dengan setelah pelayanan radiologi Periode II dipengaruhi oleh penggunaan PDH. Kesimpulan yang dapat ditarik dari hasil uji beda yaitu penggunaan PDH berlengan pendek (kelompok perlakuan) dapat menurunkan waktu mencuci tangan sebesar $0,87(34,12 \%)$.

2). Jumlah pasien yang bisa dilayani.

Peningkatan skor kinerja hasil penelitian ini sesuai dengan pendapat Mangkunegara (2005) bahwa kinerja adalah prestasi atau hasil kerja (output) berupa kualitas dan kuantitas yang dicapai per satuan Periode waktu. Peningkatan kinerja ini juga sesuai dengan UU No.5,2014, bahwa penilaian kinerja dinilai dari SKP yang dihasilkan, peningkatan nilai SKP akan dipengaruhi oleh jumlah pasien yang bisa dilayani, sesuai juga dengan pendapat Subanegara(2014). Peningkatan kinerja diupayakan dengan pendekatan ergonomi baik dari sisi tugas, organisasi kerja dan lingkungannya (Manuaba,1999). Hal ini diupayakan karena rumah sakit merupakan badan usaha yang padat karya, padat modal dan padat teknologi (Adisasmito,2008). Selain itu peningkatan kinerja di instalasi radiologi RSUP Sanglah Denpasar diupayakan untuk mencapai visi menjadi rumah sakit rujukan nasional kelas dunia di tahun 2019 dengan menjalankan fungsi dan tugas radiografer sesuai dengan Permen PAN dan RBRI No.29,2013 yang mengacu pada SPO radiologi tahun 2016, dengan tetap menggunakan PDH (PMK No 12, 2015) sesuai dengan yang digunakan tenaga medis keperawatan (PDH berlengan pendek).

\section{SIMPULAN}

PDH berlengan pendek dapat meningkatkan kenyamanan radiografer dalam melaksanakan pelayanan radiologi sebesar $\quad 10,75 \quad(27,08 \%)$ Kinerja radiografer meningkat ditinjau dari menurunnya durasi waktu mencuci tangan 
ISSN Print : 1411 -951 X, ISSN Online : 20503-1716

\section{Jurnal Ergonomi Indonesia}

\section{(The Indonesian Journal of Ergonomic)}

dalam melaksanakan pelayanan radiologi sebesar 0,87 (34,12\%), dan meningkatkan jumlah pasien yang bisa dilayani dalam

\section{DAFTAR PUSTAKA}

Adisasmito, W. 2008. Kesiapan Rumah Sakit Dalam Menghadapi Globalisasi. Jakarta: Fakultas Kesehatan Masyarakat Universitas Indonesia.

Grandjean, Kroemer. 2000. Fitting the task to the Human. A textbook of Occupational Ergonomics. Philadelpie. 5th : Taylor \& Francis.

Guyton, A.C. dan John E.H. 1997. Buku Ajar Fisiologi Kedokteran. Edisi 9. Jakarta : EGC Mukesh $G$. Harisinghani, Importance and Effects of Altered Workplace Ergonomics in Modern Radiology Suites 1.

Manuaba, A. 1998. Penerapan Ergonomi untuk Meningktan Sumber Daya Manusia dan Produktivitas. Bunga Rampai Ergonomi Vol II . Denpasar : Program Studi Ergnomi - Fisiologi Kerja Unud.

Manuaba, A. 1998. Bunga Rampai Ergonomi: Vol I. Denpasar: Program Pascasarjana ErgonomiFisiologi Kerja Unud.

Manuaba, A. 2005a. To Achieve A Better Life Through Total Ergonomic SHIP Approach Technology. Presented at the $2^{\text {nd }}$ National melaksanakan pelayanan radiologi di RSUP Sanglah Denpasar sebesar 6,31 $(53,98 \%)$.

Technology Seminar: The Application of Technology toward a Better Life, University of Technology Yogyakarta, 10 December 2005.

Peraturan Pemerintah Republik Indonesia No 53 Tahun 2010 tentang disiplin Pegawai Negeri Sipil, Jakarta: Kemntrian PAN-RB RI.

Peraturan Menteri Kesehatan Republik Indonesia, No

12/PMK/Menkes/2015 tentang pakaian Dinas Harian Pegawai Negeri Sipil di Lingkungan Kementrian Kesehatan, Jakarta: Kemenkes RI.

Peraturan Meneteri Pendayaguanaan Aparatur Negara dan Reformasi Birokrasi Republik Indonesia, No 29/PMPAN-RB/2013 tentang Jabatan fungsional Radiografer dan angka kreditnya, Jakarta: Kementrian PAN-RB RI

Tugrul, O. R. 2007. Department of Textile Engineering, Faculty of Engineering and Architecture, Cukurova University, Adana 01330, Turkey FIBRES \& TEXTILES in Eastern Europe April / June 2007, Vol. 15.

Valentino N, 2016 "The spirit of uniform. 